\title{
Dating mafic-ultramafic intrusions by monazite in hornfels: the Kabanga instrusions in the Eastern African nickel belt
}

\author{
JIAN-WEI ZI ${ }^{1,2}$, BIRGER RASMUSSEN ${ }^{3}$, JANET R. \\ MUHLING $^{3}$, WOLFGANG D. MAIER ${ }^{4}$, IAN R. FLETCHER ${ }^{2}$ \\ ${ }^{1}$ State Key Lab of Geological Processes and Mineral Resources, \\ China University of Geosciences, Wuhan (zijw@cug.edu.cn) \\ ${ }^{2}$ John de Laeter Centre, Curtin University, Australia \\ ${ }^{3}$ School of Earth Sciences, The University of Western Australia \\ ${ }^{4}$ School of Earth and Ocean Sciences, Cardiff University, UK
}

Precise and accurate dating of mafic-ultramafic intrusive rocks has proved to be a formidable task, which has impeded our understanding of their genesis and nickel sulphide mineralization. We carried out a study focused on the Kabanga-Musongati maficultramafic intrusions in the East African nickel belt, a suite of Bushveld-type layered intrusions emplaced in sedimentary sequences. We investigated metamorphic monazite crystals from the contact aureoles as well as those from the lower-grade metasedimentary rocks relatively distal to the intrusions, and undertook in situ (i.e., in polished thin section) U-Pb isotopic analyses utilizing a high-resolution ion microprobe (SHRIMP). The high- and low-grade monazites show striking contrasts in crystal morphology, chemical composition and $\mathrm{U}-\mathrm{Pb}$ age. Monazite formed by contact metamorphism in response to emplacement of maficultramafic melts is characterized by elevated $\mathrm{Th}$ and $\mathrm{U}$ contents, and yields a robust mean ${ }^{207} \mathrm{~Pb} /{ }^{206} \mathrm{~Pb}$ age of $\mathrm{c}$. $1400 \mathrm{Ma}$, in accord with ages of igneous monazite and zircon from a differentiated component of the intrusion. The results indicate that the intrusion of maficultramafic melts was substantially earlier than the prevailing $1375 \mathrm{Ma}$ S-type granites in the region, calling for a reappraisal of the widely accepted model implicating coeval, bimodal magmatism ${ }^{[1]}$. Moreover, monazite in the metapelitic rocks records two growth events at c. $1375 \mathrm{Ma}$ and $990 \mathrm{Ma}^{[2]}$, readily linked to metamorphism during emplacement of the S-type granites and tin-bearing granites, respectively. This study highlights the potential of using metamorphic monazite to determine ages of mafic-ultramafic intrusions, and to reconstruct post-emplacement metamorphic-hydrothermal history of the host terranes.

${ }^{[1]}$ Tack et al., 2010, Precambrian Research 180: 63-84

${ }^{[2]} \mathrm{Zi}$ et al., 2019, GSA Bulletin 131: 1857-1870 